\title{
Madness, Mythopoetry and Medicine
}

\author{
Temitope Ademosu, Tutiette Thomas, and Sola Adebiyi
}

'Tala kati na yo, nzela ya bonsomi',-_be the change you want to see in the world'

\subsection{Introduction}

Service users from the African diaspora consistently receive poorer mental health outcomes in the UK. A deeper delve into culture, migration history, religion, acculturative stress and trauma is required to understand how mental illness is conceptualised and responded to by many African diaspora individuals. This deep dive is often ignored or dismissed in the West, resulting in individuals from the diaspora receiving treatment that falls short of their needs.

This chapter explores through a detailed transgenerational case study, of Masimbo, who migrated with his family from Zimbabwe to the UK, to highlight the conceptualisation and journey of mental illness within an African cultural perspective. Comments are provided from all three of us as authors, respectively, a service user and former carer (Tutiette Thomas), an African healer and storyteller (Sola Adebiyi), and a systemic psychotherapist (Temitope Ademosu). The thread that binds us is our lived experiences as members of the African diaspora straddling two cultures and our passion for respecting both Western and African philosophies,

T. Ademosu ( $\square)$

Kings Global Health Institute, University of East London, London, UK

T. Thomas

South London and Maudsley NHS Foundation Trust, London Borough of Southwark,

London, UK

S. Adebiyi

Narrative Mindfulness Ltd, London, UK

(C) The Author(s) 2021 
promoting an approach in which mental illness and the nuances that culture brings is appreciated and worked with.

\subsection{Narrative History: Masimbo}

The background to Masimbo's story is the Rhodesian Bush War that broke out in the 1960s as many majority black citizens fought against the injustices of a powerful white minority rule in Zimbabwe. In its aftermath, the Gukurahundi took place, a civil conflict that lasted 4 years, resulting in nearly 20,000 war-related deaths, many of them Ndebele civilians. This legacy of European colonialism resulted in many Zimbabweans, both Ndebele and Shona, becoming displaced nationally and internationally (Fig. 1.1).

Emmerson (Masimbo's father), of Ndebele ancestry, had spent years developing his lucrative farm just outside Harare (previously Salisbury), Zimbabwe, to sustain his family. Married to his second wife Grace, who raised his five sons, Emmerson lived comfortably in his homeland. A well-known and respected member of his community, Emmerson was a vocal citizen who remained active in politics speaking out against injustices.

It was a bright, stuffy morning when Masimbo, aged 14, his father Emmerson and their family fled from Harare. The war was intensifying and showed no signs of ending. $13 \mathrm{~h}$ and 8000 miles later Masimbo and his family arrived in Cardiff airport on a dark, damp morning in 1983. Masimbo and his twin, Dakarai, soon settled into a local school. As the only black boys in the school there were several challenges both boys had to navigate alone. Their father, Emmerson, spent long hours working during the day as a bus driver and his evenings as a domestic cleaner. Their

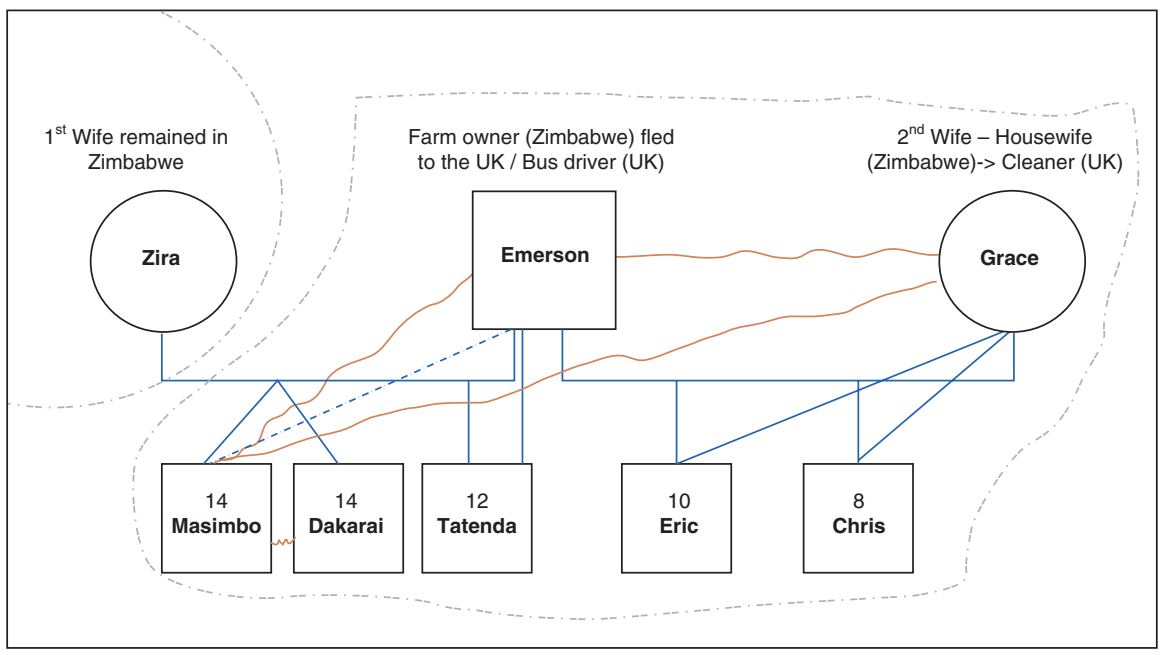

Fig. 1.1 Masimbo's family genogram 
stepmother, Grace, showered love and attention on her two biological children only, causing many tensions to arise in the family home. Incidents of conflict around relationships and finances were common.

After 3 years living in Wales, Masimbo and his family moved to Liverpool, a city in the North of the UK. Here Masimbo, by now a musically talented boy, aged 17, struggled in school both academically and socially with his peers. As a result of his quiet, shy personality he was often isolated among his peers. In contrast, his twin brother, Dakarai, was an out-going, lively bright teenager who excelled academically and was extremely popular in school. Academic success was the family currency in Masimbo's family. Emmerson wanted his sons to reclaim in the UK the life and the status they had once enjoyed in Zimbabwe, and he believed education to be the key to survival. Anything short of this was failure. Masimbo was constantly reminded of his shortcoming in this regard.

Despite these difficulties, Masimbo enrolled in university and developed a close friendship group. Girls, social drugs and alcohol were a common feature amongst many students at university and Masimbo used drugs and alcohol recreatively and enjoyed spending many hours mastering Tai chi and his guitar. Again, though, beyond his immediate group of friends, Masimbo's shy temperament led to him once again becoming isolated and feeling lonely as he was unable to connect with his peers. Emmerson, still a bus driver and domestic cleaner glowed with pride when he spoke of Dakarai who continued to be academically successfully and remained the thread and hope to keeping his dream and aspirations alive of reclaiming all he had lost in Zimbabwe. Aged 21, Masimbo now felt he had settled in life. He had a satisfying relationship with his girlfriend, Claire, whom he now lived with, and was well developed in Tai chi. His relationship with his father remained fractious.

It was Dakarai that rung him one evening and broke the news that his girlfriend Claire had cheated on him. This news made Masimbo feel like the scared, vulnerable boy who started life in Wales many years ago. Friends and family saw a steep decline in Masimbo's behaviour as he continued to withdraw into himself. He selfmedicated with cannabis, isolated himself from his few friends, and eventually ended all activities with Tai chi. Masimbo then spiralled out of control.

Recognising his decline, concerned friends and family were moved to support Masimbo. Emmerson, worried about his son immediately met with his Pastor at Church to discuss about healing for Masimbo. They strongly believed that evil spirits had entered Masimbo causing him to have this 'spirit of madness'. The Pastor offered an array of treatments for Masimbo that included a consultation, followed by prayer, fasting and deliverance for divine healing.

In 2001 Masimbo had his first mental health breakdown, a psychotic episode that resulted in his arrest and subsequent section (involuntary detention) on a mental health ward. Family, friends and Church members swarmed the ward to visit Masimbo and offer prayers, Holy oil, and a Bible to continue his process of healing. Masimbo struggled for years in and out of the wards as he often refused to take the medications prescribed for him due to their unpleasant side effects. His behaviour remained unchanged. With little improvement and no clear diagnosis being assigned to his son, Emmerson believed his own actions had aggrieved the ancestral spirits 
resulting in them withdrawing their protection from Masimbo. There was only one solution for this supernatural cause-and it could not be found in the hospital. Emmerson tapped into his transnational network and sought support from African traditional medicine, Hun'ag a from Zimbabwe, to identify the underlying cause for Masimbo's illness.

When Masimbo and Emmerson discussed this traditional approach with his clinical team, it was frowned upon. Both father and son were encouraged to continue working with his care team to support Masimbo with medication and therapy. Dismayed, Emmerson agreed to the clinical plan, but continued his pursuit of Hun'aga privately, with renewed fervour.

\subsubsection{Values Arising in the Story: What Matters or What Is Important to Those Concerned}

Sola: I spent some time with Masimbo's parents. They often stated that perhaps leaving their home was not such a good idea. His father in particular reflected that he knew people 'back home who would have known what to do'. When questioned further, he would smile cryptically and say, 'in our village there are people who have medicines for all illnesses'. It was important for Emmerson to 'tap into' his traditional resources 'back home'.

This was also an important value for Masimbo who would often announce 'my dad did not even want me to get better because he didn't even take me back home!'

Temitope: Sola's point reminds me of my childhood. It was with love that my mother would reach into the 'special cupboard' full of unnamed jars of powders, creams and soaps, with a wide array of colours. She would rub something on a bruised limb, a runny stomach or any ailment.

There are several values that grab me as I read this case study. Emmerson, migrating from Zimbabwe to the UK, lost his livelihood, status and identity in the process. It was important for him to reclaim this to make the migratory journey worth it. In turn, this sudden migration also had a strong impact on everyone in the family. His sons Masimbo and Dakarai as young boys fled from a white minority rule system in Zimbabwe to join a white majority rule in the UK. They both had to balance values as Black boys in white majority settings. Grace left the comforts of her life in Zimbabwe to work, care and support the family in the UK. Although silenced in this case study, I wonder what was important to her. Emmerson's connection with his network 'back home' and seeking healing through religion and culture appear to be Emmerson's act of love and care to his son.

Tutiette: Ubuntu ngumtu ngabanye abantu-'A person is a person through other people'.

As a service user and former carer from the African diaspora, I strongly identify with Masimbo's narrative. Although I am a second-generation UK citizen, I connect with Masimbo also having lived with the legacies of the trauma of broken attachments. Masimbo and his family faced a range of acculturative stressors when migrating from Zimbabwe to escape violence, this included as key values, legacies 
of the trauma of broken attachments through migration, and disruption of his support network that may contribute to the progression of his psychotic symptoms. In seeking to restore his son's mental health through syncretic practices, Emmerson demonstrates African/Abantu discussion of the Cartesian dualism 'Mind-Body problem' (as in the above aphorism).

\subsubsection{The Influences of Culture on the Story}

Sola: Masimbo was a young man who inherited a dichotomy of cultural influences. On one hand sat an African 'Christian' perspective that viewed mental illness as the result of demonic possession. Interestingly, this perspective also viewed traditional African practices as 'witchcraft and lead by the devil'. However, on the other hand sat an innate connection and draw to healing that drew on traditional medicine and its ability to heal.

Including the treasure chest of wisdom from humanity is crucial. The paradox proved confusing for Masimbo. Added to this mix was the Western medication which is implicitly and quietly the route that many 'civilised people' use to address mental illness. I wonder if, without the constraints and stigma towards African-led practices, Masimbo and his family would have had an array of options available to them, particularly ones they knew well.

Temitope: Emmerson, Masimbo and his siblings were born in Zimbabwe with a strong history of colonialism. Growing up in this era as middle-class Black Zimbabweans meant that families felt the visceral pain of livelihoods flushed away, lost opportunities and cheated dreams when they were displaced. The history of Zimbabwean migration to the UK is long-standing. In consequence, Emmerson held simultaneous attachments to both the UK and Zimbabwe as a result of straddling two worlds. It is important to note that despite 20 years in the UK, in various crises, it was still to Zimbabwe that Emmerson 'returned home'.

Emmerson's aetiology of mental illness was strongly linked to spiritual factors. It was important from this perspective for treatment to go beyond the physical manifestations of the problem to include underlying spiritual issues. These explanatory models of mental illness are often not acknowledged or valued by practitioners in the West. This case study, however, highlights how powerful these models are as Emmerson returns to these beliefs to seek help. The cultural and spiritual needs of Masimbo need to be addressed to cater for his physical and mental health needs.

Tutiette: For Masimbo and Emmerson, as service user and carer respectively, the Zimbabwean epistemology, called upon to resolve distress, faced epistemological injustice. Yet, much of the psychiatry and psychology workforce are trained in 'cultural sensitivity' with the aim of providing culturally competent services. If this approach was successfully implemented across the UK, Masimbo, his family and friends would have facilitated Ndebele rites of passage, including access to the psychotropic compounds of the Ndebele.

Acculturative stress and the psychological impact of adaptation to a new culture, along with trauma are factors that may have contributed to the development of 
Masimbo's crisis. The need to understand the history of this culture, and to respect the responses to it into which the African diaspora taps, is crucial.

\subsection{Storytelling as Healing in African Culture and Beyond}

With Masimbo's story in mind, it is worthwhile reminding ourselves that although many African conceptions of the universe and our place in it are different from their European counterparts, there are also parallels. These parallels become clear when we consider the role of mythopoetic stories within each tradition. In Western Christianity for example, the story of humanity's first millennium on earth has a mystical narrative, with divine beings, miraculous happenings and 'holy' visitations. The stories of Jacob, Elijah, David and others have resonance with the stories of a magical universe, not unlike that which African spiritual traditions such as that of the Yoruba, consider as their reality.

The mythopoetic universe of the Yoruba furthermore involves a range of archetypes that in the West might be called Jungian. There is though an important difference. The archetypes of the Yoruba are not 'unconscious' but very much at the forefront of the conscious minds of practitioners. These Yoruba archetypes are known as Orisa (pronounced Oree Sha), and each has a divine essential power similar to that of ancient Greek Gods. Actually, since many African peoples claim that their traditions are the descendants of those of Kemet (Ancient Egypt), and since according to Herodotus (the ancient Greek 'father of modern history'), the ancient Greeks were students of Kemetic masters, this similarity has a logical resonance.

One result of this difference is that storytelling in the Yoruba tradition is not just entertainment. To people who live in such a liminal world, their understanding of the happenings of life is actually defined by spiritual narratives. Understood in this way, their practices of choosing specific stories and poems of ancestors through divination, and mining the power of these for healing, communion and for divine solutions to mundane problems, all make complete sense. This is possible, because from such an ontological perspective, there are no mundane solutions. Everything that occurs has a spiritual precedent and the stories provide 'magical keys' to unlock the treasure trove of divine providence, bringing it to bear on specific issues. Again, this is not so very different from European traditions. As Acts 17:28 in the Christian Bible expounds 'in him we live and move and have our being', so too does the Yoruba traditionalist live, move and have their being in the mythopoetic universe of their ancestors.

All this is of course not applicable to the Yoruba alone. I (Sola) once listened to a Zulu shaman, Credo Mutwa, explain how he was taught to calm his troubled mind and also to visualise solutions to problems, through touching the eagle totem in his grandfather's house and listening to stories about it. I have experienced the power of this approach myself when, a few years ago, I was stuck in a depressive and resourceless state from which I could see no way out. I went to see a Babalawo or Yoruba Shaman. He did a divination and told me that he was guided to tell me a specific story as the 'medicine for my woes'. The story he told was of Ogun, the Orisa of iron, and how he began civilisation. This in shortened form is the story he told me. 
In the beginning of time when the Orisa came from Orun (heaven) to Ile (earth), Ile was covered by a vast impenetrable forest. All of the Orisa tried with their various mighty powers to pass through: Sango burnt trees with massive lightning bolts, Oya uprooted them with hurricanes, and Yemoya caused tsunami force tidal waves to smash them down. However their success was very limited and despite their combined might, they were unable to win through. Eventually, Ogun stepped up and using his magic sword parted the trees. The Orisa were able to pass through and civilisation began.

Having told me this story, the Babalawo asked me to visualise the forest as the deep unknown area of my unconscious mind and to recognise Ogun's sword as the will focussed on impressing the subconscious mind with its intention. I did this repeatedly also understanding that 'civilisation' was the metaphorical solution to my specific problem and that by making offerings including meditation, I would be able to intuit the antidote to the stuck place in which I found myself. Importantly, and this is crucial, I was told that through participation in tailored rituals (story enactments, songs, dances and offerings) I would also be supported by the divine power of Ogun, The Opener of The Way. I found this to be a uniquely practical and personal way to harness the omnipotence of the 'Divine' to the service of human beings.

\subsection{Conclusions}

We have shown through the story of Masimbo and his family the importance of adopting an approach to mental health care that has the flexibility to combine Western and African traditions of thought and practice. Displaced from his ancestral Zimbabwe to the UK as a young boy, Masimbo, who is rather shy and lacking in confidence, falls into a depression that proves resistant to treatment. His father, Emmerson, is ready to (as he still puts it even after over 20 years) 'take Masimbo home' to consult with a traditional healer. Consistently with his Yorubo culture, he blames himself for his son's problems believing he had alienated their ancestral spirits. But the Western mental health professionals caring for Masimbo frown on this idea. They remain in the UK, and Masimbo remains depressed. Just what the outcome of Masimbo's story would have been had a more joined up approach been offered we can only speculate. But Sola's experience as a storyteller, on which the last part of our discussion draws, suggests that it may well have had been more positive not only for Masimbo but for family, and notably his father, Emmerson.

There is a growing recognition of the need within contemporary person-centred medicine to take the spiritual needs of service users as seriously as their mental and bodily needs [1]. Masimbo's story reinforces the message of this chapter, namely of the potential contribution of mythopoetry as a resource for meeting the spiritual needs of people of the African Diaspora. Again, our view, as we have repeatedly emphasised, is not that African approaches should displace those of Western medicine. To the contrary, everything we have said in this chapter is to the effect that African mythopoetry should be made available for people of the Diaspora but 
always alongside other forms and conventions of healing including those of Western psychiatry. Neither is a panacea. If this is true for people of the Diaspora, furthermore, the similarities we have indicated in the origins and manifestations of these apparently very different traditions, suggest that there may be a role for storytelling in the African mythopoetic tradition in meeting the spiritual needs not just of people of the Diaspora but of many others as well.

\subsection{Guide to Further Sources}

For more on spirituality in Western psychiatry see the website of the Royal College of Psychiatrists Spirituality and Psychiatry Special Interest Group at: www.rcpsych. ac.uk/college/sig/spirit

\section{Reference}

1. Coyte ME, Gilbert P, Nicholls V, editors. Spirituality, values and mental health: jewels for the journey. London: Jessica Kingsley Publishers; 2007.

Open Access This chapter is licensed under the terms of the Creative Commons Attribution 4.0 International License (http://creativecommons.org/licenses/by/4.0/), which permits use, sharing, adaptation, distribution and reproduction in any medium or format, as long as you give appropriate credit to the original author(s) and the source, provide a link to the Creative Commons license and indicate if changes were made.

The images or other third party material in this chapter are included in the chapter's Creative Commons license, unless indicated otherwise in a credit line to the material. If material is not included in the chapter's Creative Commons license and your intended use is not permitted by statutory regulation or exceeds the permitted use, you will need to obtain permission directly from the copyright holder.

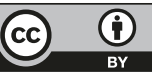

